\title{
Valuable and Vulnerable - the City in Ian McEwan's Enduring Love and Saturday
}

\section{Petr Chalupský}

Ian McEwan is one of the most prominent cartographers of modern urban life among contemporary British novelists as the city, in various forms, has featured in most of his fiction so far. This article deals with his two notably urban novels, Enduring Love (1997) and Saturday (2005), and argues that the latter can be understood as a sequel to the first in terms of its continuation of the theme of the city as a reflection of the main protagonist's mind. Yet, as the role of London in Saturday is much more complex and varied than in its predecessor, the article also focuses on how the city is used in Saturday in order to explore the theme of the relationship between the private self and outside reality, and thus attempts to demonstrate how the novel captures the Zeitgeist of the post-g/11 Western world as well as the very essence of the postmodern urban condition.

The city as both a theme and a setting has been employed in Ian McEwan's fiction from the very beginning of his career. Even though McEwan should not be labelled purely as an urban writer, the diversity of roles the city assumes in his works is notable. His early short story collections consist predominantly of stories of the urban excess, eccentricities and oddities only modern city life can generate. The absence of the city and its mechanisms of control and surveillance in an abandoned, semi-derelict suburban area indirectly allow the disordered behaviour of, and unnatural acts between, the children in The Cement Garden (1978). For Colin and Mary, the main protagonists of The Comfort of Strangers (1981), the unnamed, Venice-like, tourist town gradually transforms into a fatal labyrinth in which they become easy prey for the homicidal whims of the enigmatic, local married couple. The Child in Time (1987) depicts a dystopian vision of a near-future London with an authoritarian government, armed police and licensed begging, which represents a metaphor for the political crisis existing not only in Britain but worldwide. In Amsterdam (1998), a symbolic polarity between the cities of London and Amsterdam forms the basis of the resolution in a parable of the vanities and self-delusions of modern 
Western life. In other McEwan novels the city appears more marginally or rather as a setting: the mid-1950s Berlin of the Cold War love and espionage story, The Innocent (1990), Berlin during the fall of the Berlin Wall in Black Dogs (1992), and London during the Blitz in Atonement (2001).

Of McEwan's four remaining longer fictions, Enduring Love (1997), Saturday (2005), On Chesil Beach (2007) and Solar (2010), the first two represent distinct variations of the author's exploration of a fictional cityscape. Despite the eight years that separate their publication, Enduring Love and Saturday bear several striking resemblances and the latter can in fact be taken as a sequel to or, more precisely, a more complex continuation of, the first. Apart from the fact that they both take place in London, there are other aspects that make them related: their main protagonists are successful, happy and contented middle-aged, middle-class men in their late forties, with good jobs and flawless family lives; both are confirmed rationalists and empiricists with a profound scepticism towards or even distrust of other forms of viewing the world and attaining truth; they both become victims of another man's pathological tendencies, including intimidation and physical violence; both the stories open with an episode of immense emotional and psychological tension, with potentially life-changing consequences, not only for their protagonists; and both the stories elaborate on how modern science tends to trespass on the study of human nature, "exploring not how exotically different we are from each other, but how exotically similar we are" (Garner). At the same time, however, there are certain dissimilarities between them, namely the different narrative points of view, different significance of the opening event for the rest of the story, different causes of and motivation behind the aggressors' acts, a different treatment of time, and the different roles the city assumes in them. The aim of this article is to focus on McEwan's treatment of London in Enduring Love and Saturday and demonstrate both the parallels and divergences in his rendering of the city within their narrative frameworks.

\section{From harmony to unforgivingness - the city of/in one's mind}

Enduring Love and Saturday follow the tradition of The Cement Garden, The Comfort of Strangers and Black Dogs in their examination of "extreme, in part, deeply disturbed psychological states" (Malcolm 155), since for McEwan, "exploring morality is something that can best be done at the extremes 
of human experience" (Childs, Enduring 6), as well as the theme of the vulnerability and psychopathology of love. They also follow on from The Child in Time and Amsterdam in which the role of the city is far more complex than that of a mere setting - above all, it becomes a metaphor for the main protagonists' minds and psyches and as such it gradually transforms as the stories proceed. At the beginning of both Enduring Love and Saturday we are introduced to a rational, contented and successful, self-confident middle-aged man whose view of London, accordingly, is an optimistic or even celebratory one. In Enduring Love the house in a quiet residential part of the city where Joe Rose lives with his partner in a harmonious relationship, "an art deco apartment block in North London with a below average share of worries" (EL 8), provides a condensed image of how he sees his life - convenient, stable and secure, which can be seen from his description of the house's architectural history:

There was a time this century when ships, white ocean-going liners such as luxuriously ploughed the Atlantic swell between London and New York, became the inspiration for a form of domestic architecture. In the twenties something resembling the Queen Mary ran around Maida Vale, and all that remains now is the bridge, our apartment building. It gleams a peeling white among the plane trees. Its corners are rounded, there are portholes in the lavatories and lighting the shallow spirals of the stairwells. The steel-framed windows are low and oblong, strengthened against the squalls of urban life. (EL 54)

For Rose the building represents a lasting tradition, a comfortable yet safe and steady shelter from the chicanery of the city, an intimate oasis of peace and domestic harmony in a world of turbulent events and lurking threats.

In the opening scene of Saturday, Henry Perowne envisions his London house in a larger perspective, not as an isolated shell protecting against intrusions but as an integral part of the smoothly functioning living organism of a modern metropolis. The panegyric tone of the passage is intensified by the density of highly positively connoted terms:

[...] Henry thinks the city is a success, a brilliant invention, a biological masterpiece - millions teeming around the accumulated and layered achievements of the centuries, as though around a coral reef, sleeping, working, entertaining themselves, harmonious for the most part, nearly 
everyone wanting it to work. And the Perownes' own corner, a triumph of congruent proportion; the perfect square laid out by Robert Adam enclosing a perfect circle of garden - an eighteenth-century dream bathed and embraced by modernity, by street light from above, and from below by fibre-optic cables, and cool fresh water coursing down pipes, and sewage borne away in an instant of forgetting. ( $\left.\mathrm{S}_{5}\right)$

This positivist vision is clearly derived from the humanistic Enlightenment tradition that saw the city as a symbol of the achievements of rational reason, scientific progress and creative human endeavour. Such a milieu is an idealised, abstract one, devoid of its negative sides, an enclosed territory whose defences will forever keep the enemies at a safe distance, ante portas. It is also deeply rooted in Perowne's belief in rationalism since it subconsciously or even deliberately suppresses or omits the irrational manifestations of the city which, in their unpredictability, defy explanation by means of rational reasoning. Perowne's uncritical celebration of London perfectly reflects his euphoric state of mind: the city becomes a projection of his complacency and selfimportance, an illusory image closer to wishful thinking than any actual reality. What is, however, essential in both novels are the inconspicuous and seemingly negligible references to imperfections in the otherwise flawless descriptions of the city as they hint at the fragility of the status quo equilibrium and foreshadow the upcoming events: the "peeling white" on Rose's house suggests its vulnerability with regard to influences from outside and thus anticipates Jed Parry's invasion of Rose and Clarissa's privacy; and the fact that only "nearly everyone" wants the city to function perfectly points to the outcast, underdog and depraved whom Perowne somehow "forgets" to include in his formula expressing the city's harmony and congruence, and who all of a sudden materialises in his life in the form of Baxter and his accomplices.

We should mention one more significant aspect that notably affects the two men's elated mood when they approvingly comment on the city - they are both watching London from above, and this bird's eye view allows them to assume a detached, god-like perspective and enables them to experience the freedom of not being touched by the actual life down in the streets. Rose is sitting in a small roof garden from which he can "look towards the greenery of Hyde Park and hear the tranquillising thunder of west London's traffic" (EL 55), while Perowne, standing at a second-floor bedroom window, is looking down on the square "with the remote possessiveness of a god" (S 13). Michel de Certeau describes this experience as one that brings pleasure from totalising 
the diverse and heterogeneous city into a lucid and graspable text, the reading of which transforms one from a vulnerable walker into a complacent, remote voyeur. Set free from the city's physical texture, "[o]ne's body is no longer clasped by the streets that turn and return it according to an anonymous law; [...] His elevation transfigures him into a voyeur. It puts him at a distance. It transforms the bewitching world by which one was 'possessed' into a text that lies before one's eyes" (92). Yet, such a text, as de Certeau notes, is a mere representation of the real city below, a narrative conceived through the projection of the viewer's hopes, wishes and needs, "the panorama-city is a 'theoretical' (that is, visual) simulacrum, in short a picture, whose condition of possibility is an oblivion and a misunderstanding of practices" (93). The feeling of control and safety this perspective evokes is momentary and misleading because the city can only be approached through the practices of walking its streets, which represent "an elementary form of this experience of the city" (93), yet even these are too inconsistent to constitute its cohesive image. As both Rose and Perowne soon experience, the city in its immense otherness and fragmentariness resists any totalising reduction, it creates a text that neither the voyeur nor the walker can ever wholly comprehend.

In Saturday, the concept of the detached, graspable city gets a new dimension when Perowne examines it from the driver's seat of his luxury car. Unlike the god-like, downward-looking perspective, this is one from a position of power and confidence, but the effect is similar: a projection of the beholder's wishes and longings rather than reality. However, unlike the static text of the dehumanised city seen from above, this perspective "captures" the city's dynamism, providing an optimistic vision of its inevitable progress and development for the better. When driving along Cleveland Street, Perowne approvingly observes that the neighbourhood has changed from a shabby area of garment sweatshops and brothels into a multicultural district of international restaurants and colourful corner shops. Enclosed in the comfort and quiet of his Mercedes the external city becomes for him a safe and harmonious place:

This is the fair embodiment of an inner city byway - diverse, self-confident, obscure. And it's at this point he remembers the source of his vague sense of shame and embarrassment: his readiness to be persuaded that the world has changed beyond recall, that harmless streets like this and the tolerant life they embody can be destroyed by the new enemy - well-organised, tentacular, full of hatred and focused zeal. How foolishly apocalyptic those 
apprehensions seem by daylight, when the self-evident fact of the streets and the people on them are their own justification, their own insurance. $(\mathrm{S} 76)$

The illusion of pleasurable control is thus complemented with that of ultimate invulnerability, both personal and universal, which always overcomes Perowne when he finds himself in the safety of his "privileged, embattled sanctuary" (Heller), be it his house, car or operating theatre. Not only does he not allow for the fact that there are forces in the city whose unpredictability and uncontrollability permanently menace other dwellers' lives, he also dismisses the potential threat of a terrorist attack which, given the date still not long after $9 / 11$, suggests complacent delusion bordering on an inability or unwillingness to admit an inconvenient truth.

The abstract, theoretical London changes into a city proper when the protagonists are compelled to walk its streets and encounter physically some of the threats they contain. The description of the city differs substantially from the aforementioned self-delusive projections and once again reflects their mental disposition - full of insecurity, confusion and prone to irrational elements. When Rose runs out of the library in pursuit of Parry, whom he believes has been following him, he enters streets strangely empty of people, as if this emptiness echoed the loneliness and isolation he feels himself. He remembers the 1984 murder of a policewoman and believes that returning a flower jar to its place might bring him luck and protection against the "mad wild unpredictable forces" (EL 45) of modern urban life, a foolishly superstitious act from a person who claims to endorse a purely rationalist approach to the world. A few days later, arguing with Clarissa about how "real" Jed Parry's obsession with him is, Rose rushes out into the streets, walking furiously away in order to shake off his stalker. The afternoon is very dark with intense rain and the houses he passes transform into imaginary ones whose curtains move and give signals to those with de Clérambault's syndrome waiting outside, which incites in him a fantasy that he is a "poor down-andout", a "nothing and there was no one out here to care for [him] now" (EL 9o). The city reflects Rose's disturbed state of mind, combining fear, panic, anger and self-pity. And so when Parry gets trapped by traffic in the centre of the road Rose, instead of running away, stares at him, never quite losing "faith in the redeeming possibility of a bus crushing him as he stood there" (EL 91). Yet nothing happens to the standing Parry, shouting curses and accusations at Rose who, once again, misinterprets the situation: "I also thought that his 
condition was so extreme, his framing of reality so distorted that he couldn't harm me" (EL 91). Not even in the face of violent intimidation is Rose able or willing to realise the immediacy of the danger Parry represents for him, which is paralleled in his misreading of the conceivable consequences of this short dramatic scene.

Perowne in his car comes across the real city when he finds out that some streets are closed because of the protest march against the war in Iraq. The gathering protestors evoke in him memories of people with views of the modern world contrary to his, disturbing his optimistic flow of ideas concerning the city and leaving him "bothered by his particular state of mind, this happiness cut with aggression" (S 79). The protest in the centre of London thus not only alters the current of Perowne's thoughts but also makes him physically encounter the dark side of the city, though indirectly, as it causes the minor car accident that triggers the inconveniences he is to face later that day. It is as if the accumulation and movement of so many people stirred to life those forces of the city about which under normal circumstances one hears only from the news. The very clothes Baxter and his two sidekicks wear, "the currency of the street" (S 85), are a tell-tale sign for Perowne that he has entered a territory foreign to his understanding, yet still he is ready to use a conventional strategy for encountering strangers in the modern city, the only one he knows - inventing one's identity and play-acting this new, temporary self in the particular situation. What he does not realise is that none of the identities he is capable of assuming will be of much use when dealing with people like Baxter:

He is cast in a role, and there's no way out. This, as people like to say, is urban drama. A century of movies and half a century of television have rendered the matter insincere. It is pure artifice. [...] Someone is going to have to impose his will and win, and the other is going to give way. [...] And despite the varied and casual dress code, there are rules as elaborate as the politesse of the Versailles court that no set of genes can express. $[\ldots]$ Furthermore, nothing can be predicted, but everything, as soon as it happens, will seem to fit. (S 86-7)

Although popular culture industries and their products do significantly determine the acts of their consumers' everyday self-fashioning, to rely on films in a critical situation like Perowne's is preposterous, and, again, only demonstrates his distorted, selective view of the city which systematically 
ignores its negative aspects and displaces them from its overall image and thus causes his numerous misconceptions of those of its manifestations that do not overlap with his direct life experience. Yet, McEwan is this time merciful to his self-deluded protagonist as Perowne's ability to read the symptoms of the aggressor's wounded psyche compensates for his incapacity to read the streets of the city he lives in.

Having been through a traumatic experience, both Rose and Perowne see their city differently. Rose's understandable paranoia does not allow him to feel safe even in his house and the area surrounding it, making him look incessantly for some evidence of Parry's presence or signs of his further intentions, ironically wishing to have him within sight as that is the only way to have him under control. Perowne, back in his car, stuck in a traffic jam, observes the multitudes around and imagines how the English philosophers of the Enlightenment and men of science like Newton, Wren and their contemporaries would marvel at the teeming London streets. However, this time he does not join them as his optimism leaves him and "he can't quite trick himself into it", no longer able to glorify uncritically this "unforgiving modern city" (S 168) which, despite its manifest rationality and functionality, has shown him it can also breed forces and phenomena from the realm of the irrational, obscure and unpredictable. What connects the representations of London in Enduring Love and Saturday is that in both of the novels the city and how it is perceived by the main protagonists reflects these characters' states of mind, moods, dispositions and (mis-)conceptions. These two fictional versions of London thus serve as a narrative device for what McEwan identifies as an exceptional potential of the novel as a genre and what forms the basis of all his novels: "its peculiar ability to get inside minds and to show us the mechanics of misunderstanding" (Reynolds and Noakes 18). As both Rose and Perowne tend to perceive the city through the sometimes idealistic and simplistic prism of pure rationalism, it inevitably turns into a source of their disillusionment - although this perspective is by no means presented as essentially a bad or wrong one, it is shown as hardly sufficient to comprehend the city in its overwhelming otherness and diversity.

\section{The private and the public city}

Despite the similarity in the concept of the city of/in the mind in Enduring Love and Saturday, the role of London in the latter is considerably more complex 
and profound, as it is undoubtedly McEwan's most urban novel to date. The main reason is that while the story of Enduring Love is rather universal and could happen at almost any time in the last decades of the twentieth century as " $\mathrm{t}]$ here is no reference to contemporary politics or to any historical or social forces that might have shaped characters' lives" (Malcolm 172), the London in Saturday is historically specified into one concrete day: Saturday, February 15,2003 . The precise date suggests that it is not merely one of the days after $9 / 11$ in a city haunted by the threat of an imminent terrorist attack (and thus anticipating the 7 July 2005 suicide bombings in London's public transport system), but one whose events allow McEwan not only to probe the mental processes of his main protagonist and explore some of his favourite themes, such as how one moment can alter one's life forever or the relationship between personal and collective history, and increasing uncertainty "because of the post-war disconnection between the private and the public" (Groes 108), but also to contemplate various issues topical in the Western world at the beginning of the new millennium. McEwan explains his choice of the main protagonist for the novel's thematic framework:

One starting premise for me was let's try and invent a man who is reasonably satisfied in all quarters of his life. He doesn't have teenage kids going off the rails, he's happy in his marriage, he loves his work. Get all that out of the way then and you can start to look at how the outside world impacts. (Fray)

Saturday is the author's "first novel to engage fully with the present", exploring the troublesome position liberal Western citizens find themselves in, caught between two worlds: the "precarious happiness" of today and the "looming darker world" of tomorrow where one's "deepest fears may be realised or even eclipsed, just as any anxieties at the beginning of the twentieth century were probably no match for the horrors of Hitler, Stalin, Mao and Saddam Hussein" (Childs, Fiction 146). The city in the novel thus becomes both a setting and a medium through which McEwan composes his fragmentary image of the world in which he and his readers are destined to live.

McEwan's London in Saturday "corrects his earlier 'darkest London' by supplementing it with the traditional vision of the city as a place of light and learning, but new uncertainties, a new darkness, are brought to the fore in the post-9/11 metropolis" (Groes 111). At the basic level, the city represents a small-scale version of the Western world after September 11, especially through 
the atmosphere of fear, insecurity and tension: the emergency landing of a burning cargo airplane is automatically interpreted as a terrorist assault, while the streets crowded with marching anti-war protestors provoke a debate about the rightfulness of the US/UK-led intervention in Iraq. Therefore, Perowne's celebratory vision of the city is often tainted by the shadow of troubling world affairs, as, for instance, when he observes the swarming vitality in his beloved Fitzroy Square and, for a short while, is temped to transform into Zygmunt Bauman's "stroller", the prototypical urban gaper, and enjoy the power of projecting and directing other people's fates from the anonymous safety of his house:

They could be sisters, standing by the railings of the central gardens, oblivious to passers-by, lost to a family drama of their own. Then Perowne decides that the figure facing him is a boy. [...] Perowne is persuaded by the posture, the way the feet are planted well apart, the thickness of the wrist as he places a hand on the girl's shoulder. She shrugs him off [...] She wants the boy, she hates him. [...] People often drift into the square to act out their dramas. Clearly, a street won't do. Passions need room, the attentive spaciousness of a theatre. ( $\left.S_{59}, 60\right)$

The intriguing spectacle of city life with "no shortage of happiness either" (S 61) staged in the open space of the square seems undisturbed by any external forces, yet Perowne is not able to maintain his perspective, suddenly considering the scene's cheerfulness baffling as his thoughts divert to the situation in Iraq:

The scene has an air of innocence and English dottiness. Perowne, dressed for combat on court, imagines himself as Saddam, surveying the crowd with satisfaction from some Baghdad ministry balcony: the good-hearted electorates of Western democracies will never allow their governments to attack his country. But he's wrong. (S 62)

At this moment, Perowne takes the city and the potential threats it hides or is open to rather as two separate if not altogether unrelated things as Baxter still represents an abstract danger and the geographical distance between London and Baghdad reduces the armed conflict into a mediated TV news event. At the end of the day, however, the situation is different and Perowne, affected by all he has experienced since the early morning, envisions the city as no 
longer devoid of its dark sides. When observing the tranquility and orderliness of the nighttime square and imagining its unsuppressed vigour when it gets peopled during the day, Perowne cannot avoid taking into consideration all those who, for various reasons - social, economic, cultural or medical, "this enfeebled army haunting the public places of every town" (S 272), do not fit into the majority society that up to this point have been the sole inhabitants of his idealised cityscape. He also realises the ultimate vulnerability of the city to forces and currents from outside which can never be prevented completely in a globalised world: "London, his small part of it, lies wide open, impossible to defend, waiting for its bomb, like a hundred of other cities" (S 276). Perowne's London thus evolves from a theoretical concept reflecting his own projections, self-delusions and misconceptions into a realistic city, one that is, in its essential ambivalence, both valuable and vulnerable for all its citizens, as he is perpetually forced to negotiate and shape his relationship between the personal and the public, "between the vividness of interiority (the clarity of his private, sensuous pleasures) and the confusing demands of what lies outside" (Heller).

In many respects, McEwan's Saturday follows the tendency of mapping the city's topography through the main protagonist's mind as can be found, for instance, in Iain Sinclair's novels or in Penelope Lively's City of the Mind (1991). In Lively's novel the architect Matthew Halland experiences via the city not only his being in the world but also the mutual interconnectedness between the metropolis and its dwellers' lives:

[...] driving through the city, he is both here and now, there and then. He carries yesterday with him, and pushes forward into today, and tomorrow, skipping as he will from one to the other. [...] The whole place is a chronicle, in brick and stone, in silent eloquence, for those who have eyes and ears. For such as Matthew. Through him, the city lives and breaths; it sheds its indifference, its impervious attachment to both then and now, and bears witness. (City of the Mind 2, 3)

Halland's London is simultaneously in and out of time, a concept that echoes Peter Ackroyd's mythological and supratemporal understanding of the city that is dominated by mechanisms similar to those of our mental processes. This psychogeographic rendering of the literary city is deeply rooted in the tradition of the English urban novel as it developed in the Victorian period and took its specific course during the Modernist experiment. 
As for its narrative structure and subject matter, Saturday is much indebted to British modernist novels, namely Virginia Woolf's Mrs Dalloway $(1925)^{2}$ as it borrows several of its key motifs and ideas: it depicts one day in the life of an upper-middle-class Londoner soon after an international traumatic experience, the protagonist's moving around the city in preparation for a party enables the writer to probe her/his mind and mental processes, including meditations on mortality, and the narrative is kept in touch with the outside reality and thus somehow ordered through repeated motifs of time. Yet McEwan adopts these motifs and ideas for his own purposes: his protagonist is a man satisfied with his life and deeply in love with his wife, his moving along the city streets, even though he moves in the same area as Clarissa Dalloway, incites in him thoughts that by far transcend his personal life and return his thoughts, and the narrative along with that, to events of worldwide consequence, which is why the motifs of clocks are replaced by the various instances of news broadcasting, though "[t]ime and the city, time in the city, are at the heart of both novels" (Marcus 95). A related difference between Woolf's and McEwan's novels lies in how their protagonists perceive London: in the first, the celebration of the city is a part of the overall celebration of life, which derives its cheerfulness and hope from the fact that the war is over once and for all, while in the latter, the inherent optimism gives way to doubts, scepticism and fears resulting from a general awareness that the traumatic event only triggered other actions of a similar kind that thrust the world into a state of permanent insecurity. The continuous presence of the impending outside reality thus inevitably moves the narrative away from the modernist stream of consciousness and aesthetics towards a psychological mapping of the elusive Zeitgeist, what Dominic Head terms "a diagnostic 'slice-of-mind' novel" (192). Glancing at a TV showing the news on the wall of the changing room of the squash-court, Perowne complains of the omnipresent pressure of the problems of the outside world, "this invasion, this infection from the public domain" (S 108), that so much defines the consciousness of the contemporary city dweller.

What Saturday shares with Mrs Dalloway, despite their different historical and social backgrounds, is the contemplation of the importance of preserving one's vigour and hunger for life despite all the pitfalls of destiny. Even Baxter, spellbound by Daisy's recitation of "Dover Beach", expresses, though in his own way, his "claim on life, on a mental existence" (S 279). As the particular "valuable Saturday" (S 258) assumes a larger meaning and stands for the last period of Perowne's productive life, the city becomes a part of this metaphor: 
$[\ldots]$ this is still his Saturday, dropping far below him, as deep as a lifetime. And from here, from the top of his day, he can see far ahead, before the descent begins. Sunday doesn't ring with the same promise and vigour as the day before. The square below him, deserted and still, gives no clues to the future. (S 273)

Perowne's London, teeming, variable and unpredictable, thus symbolically represents one of the defining features of the postmodern condition of life and the ability to live it to the full, a site of changeability and diversity one has to relish before one no longer has "the strength for the square, the junkies and the traffic din and dust" (S 276). Yet it also offers countless opportunities to find a reasonable overlap between the seemingly detached private and public spheres of life and it is mainly through the city that McEwan traces "Perowne's mental and moral trajectory to some form of self-discovery and reconnection to the public realm" (Groes 108). Enduring Love thus turns out to be "an almost unremittingly psychological novel" (Malcolm 170), one a great deal more psychologically focused than Saturday, as it in detail and from different angles scrutinises its main protagonist's psyche and self-consciousness, offering thus various perspectives of psychological solipsism ${ }^{3}$ implemented in its narrative. Even though both the discussed novels are built around the transition of a city from a state of value to a state of vulnerability, Saturday takes one further step and concludes with an image of a city which contains both of these qualities as mutually inseparable attributes of existence, reflecting a "complex, paradoxical world whose multiplicity constantly perplexes and confounds us" (Groes 12). Unlike in Enduring Love where the city represents, above all, a reflection of and parallel to the main characters' psyches, a psychogeography with elements of the psycho-thriller, in Saturday it is employed and rendered in order to pose and contemplate basic, age-old ontological questions in a new era, in which the private and the public are unavoidably intertwined in an unprecedented manner.

\section{Notes}

1. Bauman describes the four major postmodern identity patterns - the stroller, the player, the vagabond and the tourist - in his Life in Fragments. Essays in Postmodern Morality, 72-104.

2. A more detailed exploration of how the city in Saturday is brought to life through intertextual references and parallelism not only to modernist works but also to the poetry of Matthew Arnold can be found in Marcus's 
"Ian McEwan's Modernist Time: Atonement and Saturday" and Groes's "Ian McEwan and the Modernist Consciousness of the City in Saturday".

3. Paul Edwards explores the theme of psychological solipsism in the novel in his article "Solipsism, narrative and love in Enduring Love".

\section{Abbreviations}

EL - Enduring Love

S - Saturday

\section{Works Cited}

Bauman, Zygmunt. Life in Fragments. Essays in Postmodern Morality. Oxford: Blackwell Publishers, 1995.

Childs, Peter, ed. The Fiction of Ian McEwan. Basingstoke: Palgrave Macmillan, 2006.

---. Enduring Love. Oxon: Routledge, 2007.

de Certeau, Michel. The Practice of Everyday Life. 1984. Berkeley and Los Angeles: University of California Press, 1988.

Edwards, Paul. "Solipsism, narrative and love in Enduring Love". Enduring Love. Peter Childs. Oxon: Routledge, 2007. 77-9o.

Fray, Peter. "The enduring talent of Ian McEwan." theage.com.au 29 January 2005. 29 March $2011<$ http://www.theage.com.au/articles/2005/o1/28/ $1106850082840 . h t m l>$. .

Garner, Dwight. "Salon Interview". salon.com 1998. 23 March 2011 <http://www.salon.com/books/int/1998/o3/cov_si_31int.html>.

Groes, Sebastian, ed. Ian McEwan. London: Continuum, 2009.

---. "Ian McEwan and the Modernist Consciousness of the City in Saturday". Ian McEwan. Ed. Sebastian Groes. London: Continuum, 2009. 99-114.

Head, Dominic. Contemporary British Novelists: Ian McEwan. Manchester: Manchester University Press, 2007.

Heller, Zoe. "One Day In the Life." The New York Times 20 March 2005. 29 March 2011

<http://www.nytimes.com/2005/o3/20/books/review/ O2OCOVERHELLER.html>.

Lively, Penelope. City of the Mind. 1991. London: Penguin Books, 1992.

Malcolm, David. Understanding Ian McEwan. Columbia: University of South Carolina Press, 2002.

Marcus, Laura. "Ian McEwan's Modernist Time: Atonement and Saturday." Ian McEwan. Ed. Sebastian Groes. London: Continuum, 2009. 83-98. 
McEwan, Ian. Enduring Love. 1997. London: Vintage, 2006.

McEwan, Ian. Saturday. 2005. London: Vintage, 2006.

Reynolds, Margaret and Jonathan Noakes. Ian McEwan: The Essential Guide. London: Vintage, 2002. 